\title{
Effect of Bovine Free Martin Serum on in vitro Development of Bovine Embryos Derived from in vitro Maturation and Fertilization
}

\author{
Hidetoshi SaTOH, Noriyuki OHISA, Naokazu TAKADA, \\ Itaru Yoshimura*, Yushi Ishikawa, Takashi Numabe \\ and Sennichi ONODERA \\ Miyagi Prefectural Animal Experiment Station, Iwadeyama-machi, \\ Miyagi-ken 989-64 \\ * Department of Animal Farm, Nippon Vetcrinary and \\ Animal Science University, Kamikuishiki-mura, \\ Yamanashi-ken 409-37
}

(Received July 12, 1994)

Key words : bovine embryo, free martin serum, in vitro culture, no co-culture

The media used for in vitro maturation and the culture of bovine in vitro-fertilized oocytes are usually supplemented with serum collected from animals ${ }^{20)}$. Requirements for the development of early mammalian embryos of domestic animals have not been defined ${ }^{16)}$. But serum may also contain components beneficial to bovine embryo development. The common serum preparations used are fetal calf serum (FCS), new born calf serum (NCS), estrous bovine serum (ES) and bovine serum albumin $(\mathrm{BSA})^{10.15 .21 \text {. }}$. However, free martin serum (FS) has never been used. Serum may enhance embryo development by providing certain growth factors, and we confirmed that the concentration of insulin like growth factor I(IGF-I) in $\mathrm{FS}$ (heat-inactivated) was higher than in other sera $(18.2 \mathrm{ng} / \mathrm{ml})$.

In this study, we attempted to evaluate the effects of free martin serum and other sera in TCM 199 for their ability to support the development of bovine embryos. We also tried to confirm the effects of IGF-I which showed a higher concentration in FS, as mentioned above.

\section{Materials and Methods}

In vitro maturation (IVM): Ovaries were collected from cows and heifers at a local slaughterhouse; maintained at $20-25^{\circ} \mathrm{C}$ and transported to the laboratory within 2 hours after slaughter. Cumulus-oocyte complexes were aspirated from small antral follicles of 2 to 8 $\mathrm{mm}$ in diameter with a $21 \mathrm{G}$ needle attached to

ウシ体外受精卵の発育に及ぼすウシフリーマーチン血清の影響 : 佐藤秀俊・大久範幸・高田直和・吉村 格*・石 川勇志・沼过 孝・小野寺千一(宮城県畜産試験場, 宮城県岩出山町 989-64*日本獣医畜産大学富士ア二マル ファーム，山梨県上九一色村 409-37) 
a $10 \mathrm{ml}$ disposable syringe. Oocytes were washed three times with tissue culture medium TCM-199 (GIBCO, NY, USA) supplemented with penicillin-streptomycin $(10 \mu \mathrm{l} / \mathrm{ml}$ : penicillin G, $10000 \mathrm{U} / \mathrm{ml}$; streptomycin, $10000 \mu \mathrm{g} /$ $\mathrm{ml}: \mathrm{GIBCO}, \mathrm{NY}, \mathrm{USA})$ and $10 \%(\mathrm{v} / \mathrm{v})$ calf serum (CS; GIBCO, NY, USA), Oocytes with intact cumulus cells and an evenly granulated cytoplasm were cultured in microdrops $(100 \mu l)$ of TCM-199 supplemented with penicillinstreptomycin and heat - inactivated CS. Oocytes were cultured for 22 hours in a $\mathrm{CO}_{2}$ incubator maintained at $38.5^{\circ} \mathrm{C}$ under $5 \% \mathrm{CO}_{2}$ in air and $95 \%$ humidity.

In vitro fertilization (IVF): In vitro fertilization was carried out using the procedures reported by TAKADA et $a l^{17)}$. Briefly, $0.5 \mathrm{~m} l$ plastic straws of frozen Japanese Black sire semen were thawed in a waterbath at $37^{\circ} \mathrm{C}$ and then washed twice with BRACKETT and OLIPHANT $^{2\}}$ medium without bovine serum albumin, but supplemented with $10 \mathrm{mM}$ caffeine, by centrifugation at $400 \mathrm{~g}$ for $5 \mathrm{~min}$. The final pellet was resuspened with the medium to adjust to a concentration of $2.0 \times 10^{7}$ spermatozoa per milliliter. An equal volume of BRACKETT and OLIPHANT medium supplemented with $10 \mathrm{mg} / \mathrm{m} l$ BSA (SIGMA, USA) and 10 I.U./ $\mathrm{m} l$ heparin (NOVO-KODAMA, JAPAN) was added to the sperm suspension. Heparintreated spermatozoa were placed in a $100 \mu l$ microdrop covered with mineral oil and the cumulus-oocyte complexes were placed in the microdrop.

In vitro culture: After six hours incubation with spermatozoa, cumulus-oocyte complexes were washed with a development medium (TCM 199 supplemented with 10\% ES) to remove excess spermatozoa.

Treatment: Seventy two hours after insemination (day 3), cumulus cells surrounding embryos were removed by pipetting and the developmental stage of the embryos was examined. In the experiment, embryos that developed into four to seven and eight-cells were randomly allocated to four treatments media: TCM 199 supplemented with $10 \%$ calf serum, $10 \%$ fetal calf serum, $10 \%$ free martin serum, $10 \%$ estrous cow serum and $10 \%$ calf serum supplemented with $50 \mathrm{ng} / \mathrm{ml}$ IGF-1 (rlGF-1; TOYOBO, JAPAN). Free martin serum was collected from three different free martin cattle ranging from 3-24 months and estrous cow serum was collected from three cows in estrus.

The total cell numbers of blastocysts in CS and FS were counted via the methods of PuRsel et $a{ }^{12}{ }^{12}$.

Statistical Analysis: The chi-square test was used to test the differences in the developmental rate to the blastocyst among the groups.

\section{Results}

The percentage of four to seven-cell embryos that developed to the blastocyst stage in ES, FS, FCS and CS were $19 \%, 44 \%, 12 \%$ and $9 \%$, respectively. Developemnt of eight-cell embryos to the blastocyst stage in ES, FS, FCS and $\mathrm{CS}$ weas $32 \%, 44 \%, 11 \%$ and $20 \%$ respectively (Table 1). The highest proportion of embryos that developed to the blastocyst stage was observed in the FS treatment. There were significant differences in the development among the groups. Furthermore, increased rate of blastocyst formation was observed in FS-TCM 199 compared with other media. The total cell numbers of blastocysts in CS and FS were $97.0 \pm 10.6$, and $113.3 \pm 9.4$. There were no significant differences among the treatments.

\section{Discussion}

Many reports exist on bovine oocytes matured, fertilized and cultured in vitro. Although the rates of in vitro maturation and fertilization are high, the developmental rate of embryos cultured in vitro is still low.

Many workers have investigated whether or not hormones and sera are necessary for in vitro maturation. The presence of serum in 
Table 1. In vitro development of bovine embryos to the blastocyst stage (day 8$)^{1}$ in different sera

\begin{tabular}{|c|c|c|c|c|c|c|c|}
\hline \multirow{2}{*}{$\begin{array}{l}\text { Embryo } \\
(\text { day } 3)^{\mathrm{I}}\end{array}$} & \multirow{2}{*}{$\begin{array}{l}\text { Estrous } \\
\text { serum }\end{array}$} & \multicolumn{3}{|c|}{$\begin{array}{l}\text { Treatments } \\
\text { Free martin serum }\end{array}$} & \multirow{2}{*}{$\begin{array}{l}\text { Fetal calf } \\
\text { serum }\end{array}$} & \multirow{2}{*}{$\begin{array}{l}\text { Calf } \\
\text { serum }\end{array}$} & \multirow{2}{*}{$\begin{array}{l}\text { Calf serum } \\
\quad+\mathrm{IGF}-1\end{array}$} \\
\hline & & $\mathrm{A}$ & $\mathrm{B}$ & $\mathrm{C}$ & & & \\
\hline $4 \sim 7$ & 19. $1 \%^{\mathrm{a}}$ & $51.5 \%^{\mathrm{b}}$ & $34.7 \%$ & $40.3 \%$ & $12.9 \%$ & 9. $2 \%^{a}$ & - \\
\hline cells & $(17 / 89)^{2}$ & $(84 / 163)$ & $(35 / 101)$ & $(25 / 62)$ & $(11 / 85)$ & $(6 / 65)$ & - \\
\hline $8 \sim$ & $32.2 \%{ }^{\mathrm{abd}}$ & $39.0 \% \%^{\mathrm{bcd}}$ & $45.0 \%{ }^{c}$ & $41.5 \%$ & $11.1 \%$ ae & $20.0 \%{ }^{a z}$ & $51.4 \%{ }^{\mathrm{cd}}$ \\
\hline cells & $(51 / 158)$ & $(16 / 41)$ & $(54 / 120)$ & $(32 / 77)$ & $(3 / 27)$ & $(10 / 50)$ & $(104 / 201)$ \\
\hline
\end{tabular}

1 insemination $=$ day 0 .

${ }^{2}$ No. of embryos to the blastocyst stage (day 8 )/No. of treated embryos

* Different superscripts are significantly different $(\mathrm{P}<0.05)$

the culture medium was necessary for oocyte maturation, fertilization and development, since sera could provide cumulus-oocy te complexes with beneficial components for in vitro maturation ${ }^{9,18,19)}$. Serum obtained from estrous cows have been used to improve in vitro maturation and fertilization rates ${ }^{20,21}$.

In the present study, the medium supplemented with FCS and CS effectively supported the development of bovine oocytes with cumulus cells. In our study, without any co-culture, free martin serum-supplemented TCM 199 resulted in a higher incidence of developed blastocysts than the other serum - supplemented TCM 199. This study has found that four-to-eight cell bovine embryos can develop into blastocysts (without a co-culture) in a culture medium containing free martin serum. Free martin serum might provide beneficial components, such as hormones, grow th factors, proteins, amino acid and some as yet undefined factors. In this study, we found that the insulin like growth factor-I level in free martin serum was high compared with heat-activated other serum. We suspect that IGF - I supported embryonic development, because the addition of IGF-I to the in vitro culture media can slightly increase the developmental rates of embryos and the number of blastocyst nuclei. HARVEY and KAYE observed that in an embryo exposed to IGF-I, protein synthesis increased, and they showed that IGF-I could interact with the insulin receptor making it unclear whether the observed affects were mediated by insulin or IGF-I receptor ${ }^{5.6)}$. RECHLER and NISSLEY reported that IGF-I could react with insulin receptors ${ }^{13)}$. KADOWAKI $e t$ al. suggested that an insulin receptor could mediate the effects of IGF-I and insulin ${ }^{8}$. Growth factors play an important role in embryonic development $t^{7}$.

It has been reported that bovine blastocysts developed in vivo had about 100 to 160 blastomeres at the blastocyst stage $e^{3,9}$. The present study resulted in lower numbers of nuclei compared with embryos produced in vivo.

The co-culture of in vitro-fertilized oocytes with cumulus cells provides an appropriate environment for bovine embryonic development $t^{1,4,11,12,14,16,19)}$. These results suggest that co-culture systems not only support embryonic development but also improve the quality of embryos produced in vitro.

In conclsion, free martin serum added to the culture medium improves the developmental capacity of bovine embryos in vitro without any co-culture. Free martin serum is a rich source of IGF-I. And perhaps, undetected components in serum would perform well in supporting embryonic development, but this no co-culture system can not improve the quality of embryos. 


\section{References}

1) AoYagi, Y., Y. Fukui, Y. Iwazumi, M. Urakawa and H. ONO, Effects of culture systems on development of in vitro fertilized bovine ova into blastocysts. Theriogenology, 34: 749-759. 1990.

2) Brackett, B.G. and G. Olphant, Capacitation of rabbit spermatozoa in vitro. Biol. Reprod., 12: 260-274. 1975.

3) FuKUi, Y. and Y. SaKuma, Maturation of bovine oocy te culture in vitro: relation to ovarian activity, follicular size and the presence or absence of cumulus cells. Biol. Reprod., $22: 669$ 673. 1980.

4) Goto, K., Y. Kajiwara, S. Kosaka, M. Kobu, Y. NAKANishi and K. OGaWA, Pregnancies after co-culture of cumulus cells with bovine embryos derived from in-vitro fertilization of in-vitro matured follicular oocytes. J. Reprod. Fertil., $83:$ 753-758. 1989.

5) Harvey, M.B. and P.L. KAyE, Insulin stimuates protein synthesis in compacted mouse embryos. Endocrinology, 122 : 1182-1184. 1988.

6) Harvey, M.B. and P.L. Kaye, Mouse blastocysts respond metabolically to short term stimulation by insulin and IGF-I through the insulin receptor. Mol. Reprod. Dev, 29 : 253-258. 1991.

7) Heyner, S., N. Shah, R.M., Smith A.J. WAtson and G.A. SchulTZ, The role of grow th factors in embryo production. Theriogenology, 39:151161. 1993.

8) Kadowaki, T., S. Koyasu, E. Nishida, H. Sakai, F. TAAKU, I. YaHARA and M. KasUGA, Insulin like growth factors, insulin and epidamal growth factor cause rapid cytoskeletal reorganization in KB cells. J. Biol. Chem., 261 : 16141-16147. 1986.

9) KajIWARA, Y., K. Goto, S. KOSAKa, Y, NakanishI and $\mathrm{K}$. OGAWA, In vitro fertilization of bovine follicular oocytes and their development up to hatched blastocysts in vitro. Jpn. J. Anim. Reperod., 33 : 173-179. 1987.

10) Leibfried, M.L., M.L. Rutledge, E.S. Critser and N.L. FrRst, Effects of fetal calf serum and bovine serum albmin on in vitro maturation and fertilizaton of bovine and hamster cumulus oocy te complex. Biol. Reprod., $35: 850-857$. 1986.

11) Mochizuki, H., Y. Fukui and H. ONo, Effect of the number of granulosa cells added to culture medium for in vitro maturation and fertilization and development of bovine oocytes. Theriogenology, 36: 973-986. 1991.

12) Pursel, V.G., R.J. Wall, C.E. ReXPoAd Jr., R.E. HAMmer and R.L. Brinster, A rapid whole mount staining procedure for nuclei mammalian embryos. Theriogenology, 31 : 687-691. 1989.

13) ReChleR, M.M. and S.P. Nissley, The nature and regulation of the receptors for insulin-like growth factors. Ann. Rev. Physiol., $47: 425$ 442. 1985.

14) Rexroad, C.E.Jr., Co-culture of domestic animal embryos. Theriogenology, $31: 105-114$. 1989.

15) Sanbuissho, A. and W.R. Threlfald, The effect of estrus cow serum on the maturation and bovine follicular oocytes in vitro(abstract). Theriogenology, $23: 226.1985$.

16) Sanbuissho, A. and W.R. Therlfall, The infuence of serum and gonadotrophins on in vitro maturation and ferilization of bovine oocytes. Theriogenology, 34:341-348. 1989.

17) Takada, N., A. Tsukamoto, Y. Kurokawa and Y. Sioy A, Effect of cumulus cells on the development of bovine oocytes matured and fertilized in vitro. (In Japanese) Jpn J. Anim. Reprod., $37:$ 9-13. 1991.

18) TAKada, N., N. OHISA, T. NUMABE and Y. IsHIKAWA, Production of twin calves by transfer of embryos produced in vitro. The Veterinary Record, 128 : 307.1991.

19) Takagi, Y., K. Mori, M. TOMizawa, T. TAKahashi, S. Sugawara and J. MASAKI, Development of bovine oocytes matured, fertilized and cultured in a serum-free, chemically defined medium. Theriogenology. 35: 11971207. 1991.

20) WANG, W.L., H.S. JiAng H.K. LU, D. MccartY and I. GORDON, The effect of media and serums on the in vitro development of early bovine embryos. Proc. Ann. Conf. Soc. Study Fert, 50 (Abstract). 1989.

21) Younis, A.I., B.G. BlACKETT and R.A. FAYRER Hoskeu, Influence of serum and hormones on bovine oocyte maturation and fertilization in vitro. Gamete Res., 23 : 189-201. 1989. 